\title{
Perspectives on Zonation in Ramsar Sites, and Other Protected Areas: Making Sense of the Tower of Babel
}

\author{
Qing Zeng*, Peter Bridgewater*, Cai Lu, Jinqi Yun, Guangchun Lei\# \\ School of Nature Conservation, Beijing Forestry University, Beijing, China \\ Email: "guangchun8099@gmail.com
}

Received 12 July 2014; revised 15 August 2014; accepted 23 August 2014

Copyright (C) 2014 by authors and Scientific Research Publishing Inc.

This work is licensed under the Creative Commons Attribution International License (CC BY). http://creativecommons.org/licenses/by/4.0/

(c) (i) Open Access

\begin{abstract}
Zonation of land or water areas is a tool frequently used to clarify management objectives, assist with monitoring of the effectiveness of those objectives and reconcile user conflicts. The Ramsar Convention has promoted zonation for wetlands as a management tool, but in a rather unstructured way, in contrast to the highly structured three-zone system of UNESCO-MAB Biosphere Reserves. At the same time, over the last 40 years IUCN has been developing a categorisation system for protected areas, currently based on management and monitoring objectives. Research undertaken primarily on wetlands in China, but with desk-top study in other regions has shown that by using these management and monitoring objectives as guiding principles, and building on the Biosphere Reserve zonation system, a new approach is possible for wetland protected or conserved areas. Developing from the three-zone system of Biosphere Reserves this new approach proposes four zones, offering more utility and flexibility for managing, monitoring and comparing wetland conservation sites, both spatially and temporally.
\end{abstract}

\section{Keywords}

Zonation, Wetland, Nature Reserve, IUCN Protected Area Categories, Ramsar, UNESCO-MAB

\section{Preamble}

The ideas developed in this paper originate from a series of studies on zonation systems used for management in wetland protected areas of China. Many, but not all, wetland protected areas in China are listed as Wetlands of

\footnotetext{
${ }^{*}$ Contributed equally to the contents of this manuscript.

${ }^{\#}$ Corresponding author.
}

How to cite this paper: Zeng, Q., Bridgewater, P., Lu, C., Yun, J.Q. and Lei, G.C. (2014) Perspectives on Zonation in Ramsar Sites, and Other Protected Areas: Making Sense of the Tower of Babel. Open Journal of Ecology, 4, 788-796. 
International Importance under the Convention on Wetlands [1] — hereafter Ramsar Convention.

We subsequently undertake a global review, comparing zonation systems proposed and used for wetlands. Building on that review, this paper attempts to explore the issues of zonation in all conserved and managed wetlands, including Ramsar sites. We also link these zonation ideas with the management objectives described under the Protected Area Category Guidelines by IUCN [2], and the zonation concepts developed for the World Network of Biosphere Reserves [3] [4].

Detailed studies on a particular Chinese wetland, Wulangsuhai [5], suggested the current zonation in use was rather too restrictive to allow all potential management options to be exercised, because of the inherent dynamism and complex spatial variation of wetlands. This implied that more thought needed to be given to principles for management zoning. There was a valid reason thus for trying to find common ground in the determination and use of zones, as well as defining a common approach to management objectives for zones so defined.

\section{Introduction}

Early studies of zonation, largely in an ecological context, began in the early 1900s with a focus largely on links between climate and vegetation. In wetlands, especially, zonation is often taken also to refer to the spatial or temporal arrangement of vegetation types.

Wetlands are among the most dynamic and productive ecosystems on Earth [6] [7], exhibiting highly dynamic ecosystem processes with seasonal changes of climate, hydrology, energy and nutrient flows. Ecosystem processes are the dynamic forces within an ecosystem that bring about changes in ecosystems over time, and influence the provision of services from those ecosystems [8]. There are many references in the literature, but Keddy [9], Mitsch and Gosselink [10] offer good summaries and Guntenspergen and Virin [11] offer perspectives on remote sensing for analyzing such ecological zonation.

Besides using zonation to describe floristic and structural variation of wetlands in space, and occasionally time, in recent decades zonation has been used as a management tool across terrestrial and aquatic ecosystems, key examples being in fisheries, and marine and terrestrial protected areas [12]-[15]. Chape et al. [16] note that "many protected areas, especially larger sites, include a range of values and management objectives that are often reflected in use and management zonation schemes within the Park".

In wetlands specifically, conservation and natural resource managers have used zoning as a useful device in allocating management effort and attention, and as means of creating coarse divisions for monitoring and managing wetlands as a landscape feature, especially those designated internationally under the Ramsar Convention or under national law. Since its creation in 1975 the Great Barrier Reef Marine Park (Australia) has moved towards a more detailed yet responsive zonation system, with greater precision on no-take zones, which helps fishers plan their activities. Its scheme encompasses seven zones that Chape et al. [16] point out are able to be mapped onto the IUCN classification system for protected areas - a matter we return to later.

Terminology relating to what a wetland is and the many forms of wetlands has become compounded and more confused in recent years, following the adoption of the terminology used by Convention on Biological Diversity (CBD), i.e. "Inland Waters" (which comprehends saline and alkaline inland lakes). At the same time some NGO's (e.g. WWF) use "freshwater" or "freshwaters" (which excludes saline and alkaline lakes) as descriptors for this ecosystem category. The Ramsar Convention defines wetlands as "areas of marsh, fen, peatland or water, whether natural or artificial, permanent or temporary, with water that is static or flowing, fresh, brackish or salt, including areas of marine water the depth of which at low tide does not exceed six metres" [1]. We use this Ramsar definition, also adopted by the Convention on Biological Diversity [17], when we refer to wetlands in our subsequent discussions.

Zones for key management activities in terrestrial conservation reserves are most frequently described as "core" or "buffer", where "core" implies a strict management regime, often protection through legal or other effective means, and "buffer" is used for an area with "low impact" human activity that enables the strict management of the core to be fully effective. More complex zonation regimes have been developed, especially in the marine realm [18]. Zones have also been given a wide range of informal titles, such as tourism zone, wilderness zone, hunting zone, research zone, etc. However, these are simply vernacular names related to one-time management options, and not implying any particular common values across wetlands from equivalent ecosystems in the same country, let alone more widely; and they do create a "Tower of Babel" effect, even for the seasoned 
practitioner.

\section{Zonation Theory and Practice}

\subsection{Zonation and the Ramsar Convention}

As the key global convention dealing with conservation and management of wetlands, the Ramsar Convention might be expected to have well-defined views on wetlands. And so the first formal discussion of zonation under the convention appears in a recommendation of the Fifth Conference of the Parties (COP) to the Ramsar Convention (Kushiro, Japan): Recommendation V. 3-The Essential Character of Wetlands and the Need for Zonation Related to Wetland Reserves [19]. Zonation was identified in this recommendation as something useful or necessary for larger wetlands, and the idea of "catchment planning" and "buffer zones" (without formal clarification or definition) was introduced to ensure that the ecological character of Ramsar sites and wetland reserves is not placed at risk, as well as emphasizing the need for careful measures for small sites. The problem here is lack of clear, quantitative, definition for what constitutes a large or small site - and of course heterogeneity, not only size, is important in determining the structure of zoning for use as a management tool.

Recommendation V. 3 brought the key Ramsar concept of ecological character into the discussion - and this issue was discussed further in considerable detail at Ramsar Conference of the Parties (COP) IX in Kampala, Uganda [20].

Resolution IX.1 Annex A, elaborated ecological character as:

"....the combination of the ecosystem components, processes and benefits/services that characterise the wetland at a given point in time."

The same Resolution linked another key Ramsar concept (wise use) and ecological character in the following definition:

"Wise use of wetlands is the maintenance of their ecological character, achieved through the implementation of ecosystem approaches, within the context of sustainable development."

So, from COP V to IX we have zonation being linked to management, and thus ensuring maintenance of ecological character and, in effect, the ensuring wise use (equivalent to the more modern term sustainable development) of the wetland [21]. The eighth Ramsar COP [22] also discussed the issue of zonation, with resolution VIII. 14 linking zonation for Ramsar sites with that for UNESCO's Man and the Biosphere Programme (MAB) Biosphere Reserves.

In China, Ramsar listed wetlands, as well as other wetland protected areas, typically have a 3-part zonation, similar, but not identical, to the UNESCO Biosphere Reserve system [3]. There is some confusion across China in the nomenclature used in zoning for management in particular wetlands, with different names being used to describe zones performing the same management function. For example, Transition area/zone, e.g. San Jiang National Nature Reserve, Dafeng National Nature Reserve, Dalai Lake National Nature Reserve [23] and experimental area/ zone/plot, e.g. Poyanghu, Yancheng National Nature Reserve, Hubei Honghu Wetlands [23], are all used as nomenclature for zones allocated for multiple sustainable use within Ramsar Sites in China.

\subsection{Zonation: Concepts and Practice under UNESCO World Network of Biosphere Reserves}

As defined in the Statutory Framework for the World Network of Biosphere Reserves [3], Biosphere Reserves should contain three zones termed core area, buffer zone, and transition area. Each Biosphere Reserve should also fulfill 3 basic functions:

Conservation - contributing to of landscape, ecosystem, specie and genetic conservation;

Development-enhancing human well-being and development which is socio-culturally and ecologically sustainable;

Logistic - providing support for research, monitoring, education and information exchange.

Originally these functions were allocated to the three zones, with very little overlap. But as we understand more about ecosystem processes and the delivery of ecosystem goods and services at landscape level (see inter 
alia [24]), the allocation of management functions needs to become more nuanced amongst the zones so as to see a zoning in a more integrated way. The transition area, besides having a development focus, can be used for conservation or wider environmental goals. The core area contributes to a range of ecosystem services (e.g. carbon sequestration, soil stabilization, supply of clean water and air, etc.) beyond providing simply for nature conservation.

Buffer zones have a special role - to minimize negative and external effects of human-induced activities on the core areas. In addition to buffering the core area for extensive human activities, buffer zone scan have their own intrinsic functions for maintaining anthropogenic, biological and cultural diversity. Buffer zones also have an important function in promoting connectivity for biodiversity between the core, transition and the wider land/seascape.

This zonation concept is applicable to all Ramsar sites which are also Biosphere Reserves [22]. Resolution VIII 14 included a very detailed work plan aimed at management planning for Ramsar sites and other wetlands, including the "provision of buffer zones around the core wetland area". The resolution further links to the ecological character concept, noting "the objective for land use within the buffer zone should be one of sustainable use through ecosystem management, consistent with the maintenance of the ecological character of the wetland".

Table 1 developed for this paper, shows the relationship of Biosphere Reserve Zonation with the functions each Biosphere Reserve must have, broken down into sub-functions. The table includes outputs from the UNESCO-MAB meeting in Madrid [4] where of the two most critical reflections on what Biosphere Reserves deliver were; the enhanced understanding of the role and importance of ecosystem services, and the need to ensure appropriate ecological infrastructure in the land/seascape. So, the ideas being accepted into planning by the Ramsar Convention and those for Biosphere Reserves begin to mirror each other.

Table 1. Biosphere Reserve zones and allowable management activities.

\begin{tabular}{lccc}
\hline \multicolumn{1}{c}{ Management activities } & Core & Buffer & Transition \\
\hline Conservation & $\sqrt{ }$ & & \\
Legal status for zone & $\sqrt{ }$ & $\mathrm{M}$ & $\mathrm{M}$ \\
Conserve biodiversity & $\sqrt{ }$ & $\mathrm{M}$ & $\sqrt{ }$ \\
Monitoring & $\sqrt{ }$ & $\sqrt{ }$ & $\sqrt{ }$ \\
Non-invasive research & & $\sqrt{ }$ & \\
Logistic & $\sqrt{ }$ & $\sqrt{ }$ & $\mathrm{M}$ \\
Non-invasive education & & $\sqrt{ }$ \\
Environmental education & & & $\sqrt{ }$ \\
Basic/applied research & & $\sqrt{ }$ & $\sqrt{ }$ \\
Development & & $\mathrm{M}$ & $\sqrt{ }$ \\
Tourism & & & $\mathrm{V}$ \\
Recreation \\
Sustainable development actions (ecosystem \\
Service provision)
\end{tabular}

Note: $\sqrt{ }$ : the original distribution of functions among the zones; M: function and zone interaction recognized after the Biosphere Reserve meeting in Madrid, Spain, 2006. 


\subsection{IUCN's Protected Area Categories}

IUCN defines [2] a protected area as:

"A clearly defined geographical space, recognised, and dedicated and managed, through legal or other effective means, to achieve the long-term conservation of nature with associated ecosystem services and cultural values".

This is different from the simpler definition under Article 2 of the CBD_-"a geographically defined area which is designated or regulated and managed to achieve specific conservation objectives" [25]—which allows for more elasticity in understanding what a protected area is and the functions it can perform.

IUCN [2] has also further considered the nature of its protected area categories and the management objectives and functions each category has. The six categories are used to achieve conservation goals, suitable to the location. If we envisage a landscape with a matrix of different but adjacent, or concentrically arranged, protected area with different IUCN categories; then each category could be envisaged as forming a "zone", with an internationally agreed and understood set of criteria for management and monitoring. Bridgewater et al. [26] used this as means of suggesting the calibration of Biosphere Reserve Zonation in a more accessible and globally uniform way (Table 2). Obviously this will not work on very small areas of land or sea, but the possibility exists for more interesting ways to develop zoning in protected areas.

\section{Discussion}

The six IUCN categories are used in different ways to achieve conservation goals suitable to the location. Table 2 shows this relationship in a 2-dimensional way. As wetlands are often connected by groundwater flows, they exist in three (or if additionally affected by strong seasonal change, four) dimensional world, and obviously some of these effects and links are also three-or four-dimensional. This temporal addition to the three-dimensional nature of ecosystem process that characterize wetlands especially necessitates more complex zonation systems [5].

Further complexity is evident when wetlands are considered in a broader landscape context [27]-[29]. Dudley [2] Noted that:

"Inland water systems are part of the larger terrestrial landscape and distinct parts are linked to their upstream catchments through a variety of above- and below-ground hydrological processes. The prospect of "fencing off" wetland systems is in most cases technically infeasible. The most effective protected areas for inland water conservation will be part of integrated river basin management (IRBM), sometimes called integrated catchment or watershed management. IRBM involves a landscape-scale strategy to achieve environmental, economic and social objectives concurrently. IRBM is a form of the Ecosystem Approach, which the State Parties to the CBD have committed to implement."

\section{Table 2. Matrix of management objectives and IUCN categories.}

\begin{tabular}{cccccccc}
\hline \multirow{2}{*}{ Management objective } & \multicolumn{7}{c}{ IUCN protected area category } \\
\cline { 2 - 7 } Scientific research & $I a$ & $I b$ & $I I$ & $I I I$ & $I V$ & $V$ & $V I$ \\
Wilderness protection & 1 & 3 & 2 & 2 & 2 & 2 & 3 \\
Species/genetic diversity preservation & 2 & 1 & 2 & 3 & 3 & - & 2 \\
Maintenance of environmental services & 1 & 2 & 1 & 1 & 1 & 2 & 1 \\
Protection of natural/cultural features & - & 1 & 1 & - & 1 & 2 & 1 \\
Tourism \& Recreation & - & 2 & 1 & 1 & 3 & 1 & 3 \\
Education & - & - & 2 & 2 & 2 & 2 & 3 \\
Ecologically sustainable use & - & 3 & 3 & - & 2 & 2 & 1 \\
Maintenance of cultural attributes & - & - & - & - & - & 1 & 2 \\
\hline
\end{tabular}

Note: 1 : primary objective; 2 : secondary objective; 3 : potentially applicable objective; -: not applicable. 
Large-scale landscape management, ensuring human benefits from the ecosystems being conserved and managed, and contributing to biodiversity conservation, are all imperatives for today's ecosystem planner and manager. But we need a more precise way to establish and describe zones used in planning and management, preferably, as noted above, within the Ecosystem Approach of the CBD [30].

A key conclusion is that Biosphere Reserve nomenclature of Core, Buffer and Transition, while long established does not, in fact, live up to the exacting standards of today's conservation needs, and needs revision and re-focusing, especially for use in wetlands ecosystems. One key area is the involvement of local people in managing any protected in which they may live. While zonation can cause confusion to local people, it can also offer a way to create awareness for them of conservation needs. CIFOR [31] describes the reasons for the lack of success of zoning schemes as:

- the process of zoning has been implemented rigidly, not adaptively;

- there are too many different zones based on unclear criteria, open to wide interpretation;

- the legal framework only accommodates one type of community (that present before the park was designated), while in reality there are many communities with different relationships and rights to the park area.

Taking account of all the above, and the fact that many recent Ramsar site nominations have been large areas that include other forms of land use and land categorisation than wetlands, it is clear we need a new paradigm for management zonation in wetlands. Table 3 shows a possible way forward building on Bridgewater et al. [26] and Zeng et al. [5].

In simple terms, our approach has been to create a three, rather than two, zone system for the buffer zone/ transition area. This will then allow for greater flexibility in developing management objectives taking into account both spatial and temporal ecological variation in the wetland under consideration.

\begin{tabular}{|c|c|c|c|c|}
\hline Management objective & Zone 1 & Zone 2 & Zone 3 & Zone 4 \\
\hline Legal status for zone & Yes & Maybe & No & No \\
\hline Scientific research & $\mathrm{e}$ & $\mathrm{p}$ & $\mathrm{n}$ & $\mathrm{n}$ \\
\hline Species/gene conservation & $\mathrm{e}$ & $\mathrm{e}$ & $\mathrm{p}$ & o \\
\hline Cultural features conservation & o & o & o & o \\
\hline Geodiversity conservation & o & o & o & o \\
\hline Eco-tourism & - & o & o & $\mathrm{n}$ \\
\hline Broad-scale tourism & - & - & o & $\mathrm{n}$ \\
\hline Recreation & - & - & - & o \\
\hline Sustainable harvesting & - & o & o & $\mathrm{n}$ \\
\hline Education activities & o & $\mathrm{p}$ & $\mathrm{p}$ & $\mathrm{n}$ \\
\hline Agriculture & - & o & o & $\mathrm{n}$ \\
\hline Sustainable forestry & - & - & - & o \\
\hline Settlements (in scale of landscape) & - & - & o & $\mathrm{n}$ \\
\hline Evolutionary possibilities for biodiversity & $\mathrm{e}$ & $\mathrm{p}$ & $\mathrm{p}$ & o \\
\hline Provisioning ecosystem services & $\mathrm{n}$ & o & $\mathrm{p}$ & $\mathrm{p}$ \\
\hline Regulating ecosystem services & $\mathrm{e}$ & $\mathrm{e}$ & $\mathrm{p}$ & $\mathrm{p}$ \\
\hline Supporting ecosystem services & e & $\mathrm{e}$ & e & $\mathrm{e}$ \\
\hline Cultural ecosystem services & $\mathrm{n}$ & o & $\mathrm{p}$ & $\mathrm{p}$ \\
\hline
\end{tabular}

Note: e: essential conservation management function; n: non-threatening management function; o: optional management function; $\mathrm{p}$ : priority conservation management function; -: inapplicable management function. 
In zoning wetlands for management, much depends on two key variables: size and complexity (or, more simply, heterogeneity). It is therefore likely that not every wetland will need all four zones, i.e., a wetland management plan could consist of zones 1, 2 and 4, or 1, 3 and 4, or even just 1 and 4, if the management regime is robust enough [5]. Very small wetlands set in a well-managed landscape, may have just a single zone, and typically - but not always - type 1 . The overriding principle is that zonation must be clearly linked to management objectives and legal or administrative designation of the wetland, Ramsar site or not.

\section{Establishing Zonation Structure}

Ramsar Resolution VIII. 14 had some advice on establishing wetland zonation, including:

- Zonation should be established with the full involvement of stakeholders, including local communities and indigenous peoples. Those who neglect essential rural livelihoods and sustainable resource utilization are most likely to foster antagonisms;

- A full and detailed rationale should be made to explain the basis for establishing and delineating zones and this is particularly important when establishing the limits of buffer zones;

- A concise description of the functions and/or restrictions applied within each zone must be prepared as part of the management plan;

- Zones should be identified with a unique and, if possible, meaningful code or name: but in some cases, a simple numerical code may be adequate;

- A map showing the boundaries of all zones must be prepared using a Global Positioning System (GPS) where possible to avoid ambiguity, and using obvious geographical features so the boundaries can be easily recognized in the field by managers and wider public alike.

In practical terms, a zonation structure can be established using maps or aerial photographs of the wetland. If the model described above is to be used, then a simple method of allocating major management needs for the wetland can be achieved as follows:

- Cover the map or aerial photograph with a grid of suitable size, which will depend on the size and scale of the wetland under consideration;

- For each grid cell the management objectives can be summarized, using the matrix of zones and management objectives as shown in Table 3;

- For those cells with mostly Zone 1 objectives, they form Zone 1; mostly Zone 2 objectives zone 2-and so on. After this analysis a draft zonation map can be produced, field-tested, and then a final map developed with the required precision. It should be noted though that often precision is unhelpful and boundaries that are fuzzy or flexible can be more helpful to a manager, and assist stakeholders discharge their responsibilities. While the zones and objectives are presented as fixed spatial entities, because of the dynamism typical of wetlands discussed earlier, if sustainable utilization is in place, then the zones can be used also to control management in a temporal way.

For example, a wetland zone 3 in which there is a sustainable fishery might be given zone 1 status at some times of the year to ensure adequate reproduction potential for the fish. Zone 3 also has the best potential for providing connectivity within the wetland reserve, while Zone 4 has the best potential for connectivity with the adjacent landscape. Zeng et al. [5] give a worked example of this. Development of ecological infrastructure is an important issue as it allows the flow of species and genes across boundaries, and to the wider landscape [32] [33]. As some species/genes may have undesirable effects on long-term ecological functioning, and thus on ecosystem service delivery, appropriate design of such infrastructure is critical.

\section{Recommendations}

Zones described using local vernacular terms, however vague, can assist local stakeholders and immediate managers understand more effectively what management is required to be undertaken. We note, however, that vernacular names for zones which relate to specific management options do not imply any particular common values across equivalent wetlands. That said, there may well be a local issue where a zone or zones are seen to be important for over-riding management or conservation objectives, feeding or breeding space for migratory waterfowl, and contributing to integrated management at catchment or coastal zone level, and so on.

The abstract naming of zones 1-4 may offer neutrality, and may remove pre-conceptions about the nature of the Zone. However, IUCN attempted such a neutral approach in developing its protected areas categories in 
1994, but this proved to be a failure, as there was a clamour for a "common name" to be used besides the Category type! Indeed, many managers would prefer to have a name for the zones they have to allocate and manage.

Embracing both viewpoints, and in order to offer plain language names for the four zones proposed in this paper, we suggest the following reflecting the key management purposes for the zones:

Zone 1 - core (high conservation, legally or effectively protected) zone;

Zone 2-limited use zone;

Zone 3-wise use zone;

Zone 4-risk control (connectivity) zone.

Zone 2 and Zone 3 have especial role - to minimize negative and external effects of human-induced activities on Zone 1. They can have their own intrinsic functions for maintaining anthropogenic, biological, cultural diversity. And besides, they can also have an important function in promoting connectivity from Zone 1 to Zone 4 and beyond the wider land/seascape. Such connectivity is now recognized as critical to the development of resilience and coherence in protected area networks [33] [34]. At all times the watchword should be simple and practical, while having in mind the views and needs of stakeholders and taking different management objectives into account. It is worth remembering that while the basis of zonation must be scientific, the final product is an art form and hopefully an art form that speaks a universal language.

It seems clear that in managing wetlands, whether protected by Ramsar designation, as part of UNESCO Biosphere Reserves, declared under national law, or existing simply as part of a non-protected but managed landscape feature, zonation can be a useful aid in allocating management effort and attention. But as a management tool to reconcile different user conflicts in protected areas more generally, zonation concept and practice do need better focus; we hope the ideas in this paper go some way towards providing that focus.

\section{References}

[1] Ramsar (1971) Convention on Wetlands of International Importance Especially as Waterfowl Habitat. http://www.ramsar.org/cda/en/ramsar-documents-cops-1971-final-act-of-the/main/ramsar/1-31-58-136\%5E20803 400 0 을

[2] Dudley, N. (2008) Guidelines for Applying Protected Area Management Categories. IUCN, Gland.

[3] UNESCO (1995) Biosphere Reserves: The Seville Strategy \& The Staturory Framework of the World Network. http://unesdoc.unesco.org/images/0010/001038/103849Eb.pdf

[4] UNESCO (2006) Madrid Action Plan for Biosphere Reserves (2008-2013). http://unesdoc.unesco.org/images/0016/001633/163301e.pdf

[5] Zeng, Q., Zhang, Y., Jia, Y., Jiao, S., Feng, D., Bridgewater, P. and Lei, G. (2012) Zoning for Management in Wetland Nature Reserves: A Case Study Using Wuliangsuhai Nature Reserve, China. SpringerPlus, 1, 1-10. http://dx.doi.org/10.1186/2193-1801-1-23

[6] Gibbs, J.P. (1993) Importance of Small Wetlands for the Persistence of Local Populations of Wetland-Associated Animals. Wetlands, 13, 25-31. http://dx.doi.org/10.1007/BF03160862

[7] Whittaker, R.H. and Likens, G.E. (1973) Primary Production: The Biosphere and Man. Human Ecology, 1, $357-369$. http://dx.doi.org/10.1007/BF01536732

[8] Carpenter, S.R., Mooney, H.A., Agard, J., Capistrano, D., DeFries, R.S., Díaz, S., Dietz, T., Duraiappah, A.K., OtengYeboah, A. and Pereira, H.M. (2009) Science for Managing Ecosystem Services: Beyond the Millennium Ecosystem Assessment. Proceedings of the National Academy of Sciences of the United States of America, 106, 1305-1312. http://dx.doi.org/10.1073/pnas.0808772106

[9] Keddy, P.A. (2010) Wetland Ecology: Principles and Conservation. Cambridge University Press, Cambridge. http://dx.doi.org/10.1017/CBO9780511778179

[10] Mitsch, W.J. and Gosselink, J.G. (2007) Wetlands. John Wiley \& Sons, Inc., Hoboken.

[11] Guntenspergen, G.R. and Virin, B.A. (1998) Vulnerability of Coastal Wetlands in the Southeastern United States: Climate Change Research Results. DTIC Document, 1992-1997.

[12] Babcock, E.A., Pikitch, E.K., McAllister, M.K., Apostolaki, P. and Santora, C. (2005) A Perspective on the Use of Spatialized Indicators for Ecosystem-Based Fishery Management through Spatial Zoning. ICES Journal of Marine Science, 62, 469-476. http://dx.doi.org/10.1016/j.icesjms.2005.01.010

[13] Davos, C.A., Siakavara, K., Santorineou, A., Side, J., Taylor, M. and Barriga, P. (2007) Zoning of Marine Protected Areas: Conflicts and Cooperation Options in the Galapagos and San Andres Archipelagos. Ocean \& Coastal Management, 50, 223-252. http://dx.doi.org/10.1016/j.ocecoaman.2006.03.005 
[14] Day, J.C. (2002) Zoning_Lessons from the Great Barrier Reef Marine Park. Ocean \& Coastal Management, 45, 139156. http://dx.doi.org/10.1016/S0964-5691(02)00052-2

[15] Salomon, A.K., Waller, N.P., McIlhagga, C., Yung, R.L. and Walters, C. (2002) Modeling the Trophic Effects of Marine Protected Area Zoning Policies: A Case Study. Aquatic Ecology, 36, 85-95. http://dx.doi.org/10.1023/A:1013346622536

[16] Chape, S., Spalding, M. and Jenkins, M.D. (2008) The World's Proteced Areas. UNEP-WCMC in Association with University of California Press, Oakland.

[17] CBD (2010) Inland Waters Biodiversity —What Is It? http://www.cbd.int/waters/inland-waters/

[18] Wells, S. and Day, J. (2004) Application of the IUCN Protected Area Management Categories in the Marine Environment. Parks, 14, 28-38.

[19] Ramsar (1993) The Essential Character of Wetlands and the Need for Zonation Related to Wetland Reserves. http://www.ramsar.org/pdf/rec/key_rec 5.03e.pdf

[20] Ramsar (2005) A Conceptual Framework for the Wise Use of Wetlands and the Maintenance of Their Ecological Character. http://www.ramsar.org/pdf/res/key res ix 01 annexa_e.pdf

[21] Bridgewater, P. (2008) A New Context for the Ramsar Convention: Wetlands in a Changing World. Review of European Community \& International Environmental Law, 17, 100-106. http://dx.doi.org/10.1111/j.1467-9388.2008.00582.x

[22] Ramsar (2002) New Guidelines for Management Planning for Ramsar Sites and Other Wetlands. http://www.ramsar.org/cda/en/ramsar-documents-resol-resolution-viii-14-new/main/ramsar/1-31-107\%5E21393 4000 $\underline{0}$

[23] Ramsar (2013) Ramsar Information Sheets and Maps. http://ramsar.wetlands.org/Database/SearchforRamsarsites/tabid/765/Default.aspx

[24] MA (2005) Millennium Assessment Reports. http://www.maweb.org/en/index.aspx

[25] CBD (2010) Use of Terms. http://www.cbd.int/convention/articles.shtml?a=cbd-02

[26] Bridgewater, P. (1996) Biosphere Reserves and the IUCN System of Protected Area Management Categories. Australian Nature Conservation Agency, the World Conservation Union and the UNESCO Man and the Biosphere Programme.

[27] Abell, R., Thieme, M., Ricketts, T.H., Olwero, N., Ng, R., Petry, P., Dinerstein, E., Revenga, C. and Hoekstra, J. (2011) Concordance of Freshwater and Terrestrial Biodiversity. Conservation Letters, 4, 127-136. http://dx.doi.org/10.1111/j.1755-263X.2010.00153.x

[28] Higgins, J.V. (2003) Maintaining the Ebbs and Flows of the Landscape: Conseivation Planning foi Fieshwatei Ecosystems. In: Groves, C.R. and contributors, Eds., Drafting a Conservation Blueprint: A Practitioner's Guide to Planning for Biodiversity, Island Press, Washington DC, 291.

[29] Revenga, C., Campbell, I., Abell, R., de Villiers, P. and Bryer, M. (2005) Prospects for Monitoring Freshwater Ecosystems towards the 2010 Targets. Philosophical Transactions of the Royal Society B: Biological Sciences, 360, 397-413. http://dx.doi.org/10.1098/rstb.2004.1595

[30] CBD (2010) Ecosystem Approach. http://www.cbd.int/ecosystem/

[31] Mulyana, A., Moeliono, M., Minnigh, P., Indriatmoko, Y., Limberg, G., Utomo, N.A., Iwan, R., Saparuddin and Hamzah (2010) Establishing Special Use Zones in National Parks: Can It Break the Conservation Deadlock in Indonesia? Center for International Forestry Research (CIFOR), Bogor.

[32] Bennett, A.F. (1999) Linkages in the Landscape: The Role of Corridors and Connectivity in Wildlife Conservation. IUCN, Gland.

[33] Ervin, J., Mulongoy, K., Lawrence, K., Game, E., Sheppard, D., Bridgewater, P., Bennett, G., Gidda, S. and Bos, P. (2010) Making Protected Areas Relevant: A Guide to Integrating Protected Areas into Wider Landscapes, Seascapes and Sectoral Plans and Strategies. CBD Technical Series, No. 44, 5.

[34] WWF (2007) Protected Network of Giant Panda and Wetlands in Yangtze River. http://en.wwfchina.org/en/who_we_are/critical_ecoregions 
Scientific Research Publishing (SCIRP) is one of the largest Open Access journal publishers. It is currently publishing more than 200 open access, online, peer-reviewed journals covering a wide range of academic disciplines. SCIRP serves the worldwide academic communities and contributes to the progress and application of science with its publication.

Other selected journals from SCIRP are listed as below. Submit your manuscript to us via either submit@scirp.org or Online Submission Portal.
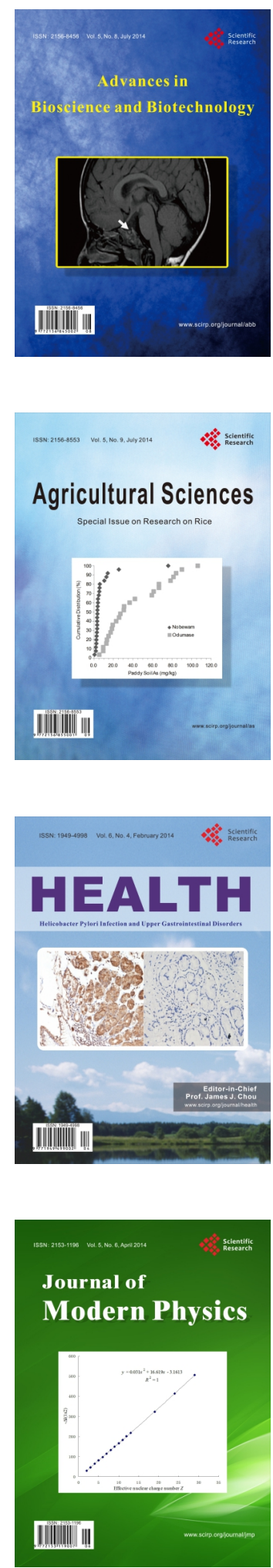
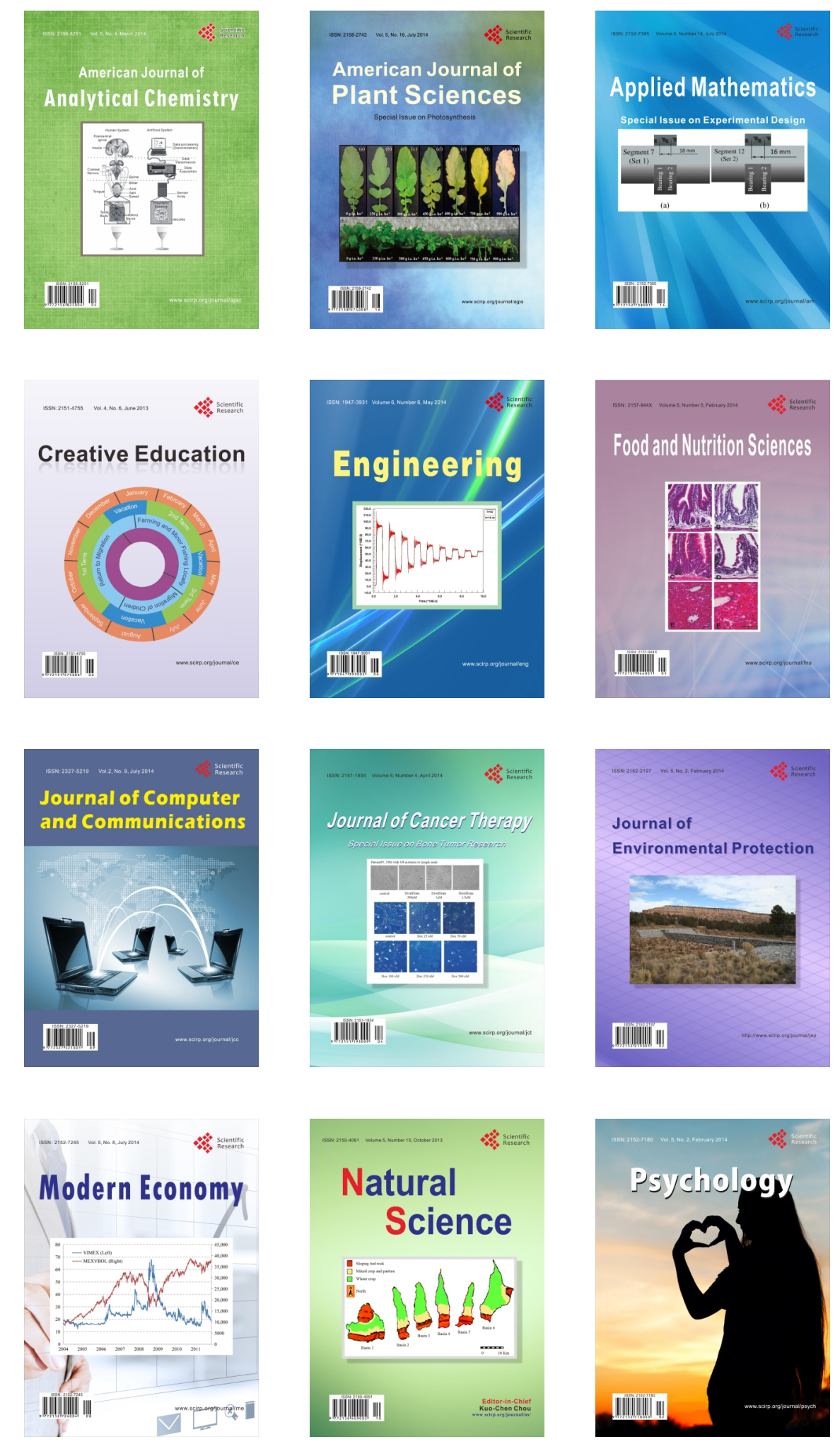